\title{
Archæology and Surveying in Southern Rhodesia.
}

W

$\mathrm{E}$ have at times had occasion to refer to difficulties placed in the way of archæological and ethnological research owing to vexatious regulations imposed by the governments of the countries in which research is to be prosecuted. It is not of ten that the other side of the picture is presented, and that an accredited expedition is known to have abused the privileges that have been granted. Our attention has been directed to a particularly flagrant case. The official report of the Debates of the Legislative Assembly of Southern Rhodesia for May 7 records a reference to the case of Dr. Frobenius, who, it will be remembered, conducted an expedition in Rhodesia in 1929 and communicated some of the results of his investigations at Zimbabwe and elsewhere to the South African meeting of the British Association in that year. Dr. Frobenius, it is stated, was in receipt of substantial assistance from the Government of Southern Rhodesia. A money grant of $£ 92: 4: 0$, reprosenting half the costs, was supplemented by an equivalent share borne by the railways, and, in addition, a native commissioner was granted six weeks leave on full pay to assist him.

Notwithstanding the fact that, in return, Dr. Frobenius entered into an agreement to share any finds equally with the Government and to submit any specially valuable find to arbitration, the whole of the relics found were removed from the country without the knowledge of the Government. When this was condoned on the condition that they were divided up at Cape Town, thoy were removed to Germany. Since then Dr. Frobenius has returned such objects as ho considers the share of the Government, and has refused either to return or to submit to arbitration the only gold object stated by him to have been found within the Colony. The Colonial Secretary, in making a statement on the matter, was good enough to contrast the action of Miss Caton-Thompson, on behalf of the
British Association, in returning all her finds to the Colony.

According to the official report of the debates in the Legislative Assembly of Southern Rhodesia, in the debate on the estimates the deletion was moved of the itom "Geodetic and Secondary Triangulation, £5000." In defending the appropriation the Minister of Agriculture and Lands pointed out not only that every self-respecting colony undertakes work of this kind as early as possible in its history, but also that had Southern Rhodesia started it earlier a great deal of money would have been saved. It would appear that much of the present cost of the Geological Survey is due to the fact that, before the Geological Department can pursue its legitimate work of mapping the geological formations, much preliminary work has to be done, which is made necessary by the fact that there is no. Ordnance Survey to which reference can be made. Indeed, it was stated by another member that the surveyors who are engaged in the work of triangulation often have to refer to the Geological Survey for information. The Minister also referred to the position in the Union of South Africa. In the Boer war it was found that the maps of the country were utterly defective and a reproach. Immediately after the Union a triangulation of the whole country was begun, and the expenditure now stands at $£ 20,000$ a year. The result is that, as the Director states, the triangulation of the Union, which is just about com. pleted, is as fine as any in the British Empire. The motion to delete the appropriation was withdrawn.

In the same debate reforence was made to expenditure on afforestation, in which Southern Rhodosia is also pursuing a forward policy. Indeed, throughout the debates it is encouraging to note that the members of the Legislature are fully alive to the advantages of the application of science to the development of the colony, even if not immediately remunerative.

\section{Exhibition of British Optical Instruments.}

'THE Loan Exhibition of British Optical Instruments which was opened at the Science Museum, South Kensington, on Aug. 28, will remain on view until the end of October, and will provide the public with an opportunity to see collected together in a comparatively small space representative exhibits contributed by most of the important optical firms in Great Britain.

Binoculars are very adequately represented by the exhibits of Messrs. Ross and Messrs. Barr and Stroud, among those of the former being a three power prism binocular telescope with objective aperture of $60 \mathrm{~mm}$. Telescopes are exhibited by Messrs. Ross and Messrs. W. Ottway and Co., the latter firm showing also a selection of stainless steel mirrors. Photographic objectives designed for special purposes, such as aerial photography, the projection and taking of cinema pictures, etc., have received considerable attention by British manufacturers in recent years, and these are included in the lenses shown by Messrs. Ross and Messrs. Taylor, Taylor and Hobson. A portable cinematograph, taking standard size films, is notable amongst Messrs. Ross' exhibits.

Among the surveying instruments is the Tavistock theodolite, reading to one second of arc, which is made by Messrs. Cooke, Troughton and Simms, who are also exhibiting a $45^{\circ}$ prismatic astrolabe. This instrument has been designed for the accurate determination of latitude and longitude on shore, and has been used with marked success by the Hydrographic Service of the Admiralty. Messrs. E. R. Watts and Son are showing a selection of ' constant' bubbles, the air-bells of which remain the same length over a wide range of tomperature, a vertical magnetic force variometer, and various surveying instruments. A selection of 'Heath' sextants is shown by Messrs. W. F. Stanley and Co.

The collection of microscopes includes a new binocular instrument made by Charles Perry, according to the design of Prof. D. M. S. Watson, of University College, London, and a new model Vickers projection microscope. The latter, which is of very robust design, taking objects up to $50 \mathrm{lb}$. in weight, can be used for opaque or transparent objects at magnifications of from 3 to 5000 diameters, and is fitted up for demonstration. Othor firms exhibiting microscopes are Messrs. J. Swift and Sons, Messrs. C. Baker, and Messrs. W. Watson and Sons. The lastnamed firm is exhibiting also a selenium densitometor, designed by the British Photographic Research Association, for determination of the density of photographic negatives.

An aerial camera, of a type which has boon used all over the world, is exhibited by the Williamson Manufacturing Co. This takes 100 photographs $(9$ in. $\times 7$ in.) with one filling. Topographical stereoscopes designed for use in examination of aerial photographs 